\title{
Clinical impact of depression and anxiety in patients with non-cystic fibrosis bronchiectasis
}

\author{
Melahat BEKIR ${ }^{1}($ ID) \\ Derya KOCAKAYA ${ }^{2}(I D)$ \\ Baran BALCAN $^{2}$ (ID) \\ Şehnaz OLGUN \\ YILDIZELi $^{2}$ (ID) \\ Emel ERYÜKSEL ${ }^{2}(I D)$ \\ Berrin CEYHAN $^{2}$ (ID)
}

\author{
${ }^{1}$ Department of Chest Diseases, Faculty of Medicine, Okan University, \\ Istanbul, Turkey \\ ${ }^{1}$ Okan Üniversitesi Tıp Fakültesi, Göğüs Hastalıkları Anabilim Dalı, \\ istanbul, Türkiye \\ 2 Department of Chest Diseases, Faculty of Medicine, Marmara University, \\ Istanbul, Turkey \\ 2 Marmara Üniversitesi Tıp Fakültesi, Göğüs Hastalıkları Anabilim Dalı, \\ istanbul, Türkiye
}

Cite this article as: Bekir M, Kocakaya D, Balcan B, Olgun Yıldizeli Ş, Eryüksel E, Ceyhan B. Clinical impact of depression and anxiety in patients with non-cystic fibrosis bronchiectasis. Tuberk Toraks 2020:68(2):103-111.

\section{Yazışma Adresi (Address for Correspondence)}

\section{Dr. Baran BALCAN}

Marmara Üniversitesi Tıp Fakültesi, Göğüs Hastalıkları Anabilim Dalı, ISTANBUL - TÜRKIYE

e-mail: drbaranbalcan@yahoo.com

CCopyright 2020 by Tuberculosis and Thorax.

Available on-line at www.tuberktoraks.org.com

\begin{abstract}
Clinical impact of depression and anxiety in patients with non-cystic fibrosis bronchiectasis

Introduction: Bronchiectasis is a chronic suppurative disease characterized by abnormal bronchial dilatation. The nature of bronchiectasis may have negative impact on psychological status, however it is poorly studied in relation to clinical indices, particularly the severity of disease. Primary aim of this study is to detect depression and anxiety in patients with non-cystic fibrosis bronchiectasis and to evaluate its relationship with disease severity indexes.
\end{abstract}

Materials and Methods: Ninety (male/female $=37 / 53 ;$ median age 45 years) stable non-cystic fibrosis bronchiectatic adult patients were enrolled into this study. Dyspnea scores, number of exacerbations and hospital admissions within the last year, body-mass index, pulmonary function tests, sputum cultures, bronchiectasis disease severity indexes (BSI and FACED) were assessed. Anxiety and depression were evaluated by using the Turkish version of the hospital anxiety and depression scale questionaire.

Results: Anxiety was diagnosed in 30\% of patients and depression was diagnosed in $41 \%$ of the participants. Female participants had significantly higher rates of depression (55\% vs. $22 \%$; $p=0.002$ ). Exacerbation rates within the last year were higher among the subjects with anxiety, moreover, patients with depression had shorter duration of disease. BSI and FACED severity indexes increased with longer duration of disease $(5.6 \pm 5.0 \mathrm{yrs}$ in mild group vs. $10.1 \pm 9.2 \mathrm{yrs}$ in moderate-to-severe group, $p=0.035$ and $5.7 \pm 5.4 \mathrm{yrs}$ in mild group vs. $12.1 \pm 9.7 \mathrm{yrs}$ in moderate-to-severe group, $p=0.001$, respectively), however, anxiety and depression were not related with BSI and FACED severity indexes. 
Conclusion: Patients with non-cystic fibrosis bronchiectasis have an increased risk for depression and anxiety. Duration of disease and higher exacerbation rate are related with psychological status and indexes increased with longer duration of disease. Early detection and taking the necessary measures to improve the psychological state is necessary for the overall management of these patients.

Key words: Depression; anxiety; bronchiectasis

\section{ÖZ}

\section{Depresif ve endişe duygudurumunun kistik fibrozis olmayan bronşektazi hastalarının kliniği üzerindeki etkisi}

Giriş: Bronşektazi hastalığı, düzeyi farklı varyasyonlar göstermekle beraber, anormal bronş dilatasyonu ile seyreden bir hastalıktır. Bronşektazi psikoloji üzerine negatif etki yapabilir. Bronşektazi hastalarında klinik ve hastalık derecesiyle psikoloji arasındaki ilişki bugüne kadar çok fazla değerlendirilmemiştir. Bu çalışmadaki temel amacımız, kistik fibrozis olmayan bronşektazi hastalarında depresyon ve endişe duygudurumunun ve bunun BSI ve FACED gibi hastalık derecesini gösteren belirteçlerle olan ilişkisinin değerlendirilmesidir.

Materyal ve Metod: Bu çalışmada stabil dönemdeki toplam 90 (kadın/erkek=37/53; ortalama yaş 45) bronşektazi hastası değerlendirildi. Dispne skorları, son bir yıl içerisindeki alevlenme ve hastane yatışı, beden kitle indeksi, solunum fonksiyon testleri, balgam kültürleri, BSI ve FACED indeksleri değerlendirildi. Endişe ve depresif duygudurumları Türkçe validasyonu yapılmış "hospital anxiety and depression" ile değerlendirildi.

Bulgular: Endişe duygudurumu katılımcıların \%30'unda, depresyon \% 41'inde tespit edilmiştir. Erkeklere kıyasla kadınlarda depresyon daha fazla gözlenmiştir (\%55 vs. \%22, p=0.002). Endişe duygudurumu gözlenenlerde, son bir yıl içerisindeki alevlenme sayısının daha fazla olduğu izlenmiştir $(3.7 \pm 2.0$ vs. $2.5 \pm 1.8, p=0.007)$. Depresyonu olan hastalarda, hastalık süresinin daha az olduğu gözlenmiştir (5.4 \pm 6.0 yıl vs. $9.5 \pm 8.3$ yıl, $p=0.004$ ). Hastalık süresi uzadıkça BSI (hafif hastalarda $5.6 \pm 5.0$ yıl vs. orta ileri grupta $10.1 \pm 9.2 \mathrm{yll}, p=0.035$ ) ve FACED (hafif grupta $5.7 \pm 5.4 \mathrm{yll}$ vs. orta ileri hastalarda $12.1 \pm 9.7 \mathrm{yll}, p=0.001$ ) indeks değerlerinin daha yüksek olduğu izlenmiştir, ancak endişe duygudurum ve depresyonla BSı ve FACED arasında anlamlı bir ilişki bulunmamıştır.

Sonuç: Bu çalışmada elde ettiğimiz sonuçlar kistik fibrozis olmayan bronşektazi hastalarında depresyon ve endişe duygudurum riskinin daha fazla olduğunu, özellikle bu riskin kadınlar için daha fazla olduğunu göstermektedir. Hastalık süresi ve alevlenme sayısının psikolojik durumla ilişkili olduğu ve hastalık belirteci indekslerde hastalık süresi uzadıkça artış olduğu sonucuna varılmışır. Duygudurumdaki bozulmaların erken tespit edilmesi ve bu durumun düzeltilmesinin hastalık yönetiminde önemli olduğu düşünülmektedir.

Anahtar kelimeler: Depresyon; endişe duygudurum; bronşektazi

\section{INTRODUCTION}

Bronchiectasis is defined as the pathologically irreversible, abnormal dilatation of the bronchi. The prevalence of non-cystic fibrosis (CF) bronchiectasis and multi-morbid conditions are rising worldwide and is imposing a burden on healthcare systems. This growth demands a best delivery of care for people living with this disease. Psychosocial factors in patients with chronic respiratory symptoms may also contribute to the impairment of their health status. Several studies showed that patients with chronic diseases have increased risk for development of anxiety and depression (1). They may be frequently overlooked in daily practice. There are scant published data on the psychological status of patients with nonCF bronchiectasis, which are unfortunately largely extrapolated from cystic fibrosis and chronic obstructive pulmonary disease (COPD) studies. Psychiatric disorders such as anxiety and depression are more prevalent in subjects in chronic airway diseases such as COPD and asthma. In the litarature depression and anxiety were observed more than the half of the patients with bronchiectasis. It has also been reported that depression and anxiety are associated with worse health outcomes in subject with bronchiectasis regarding dyspnea, low forced expiratory volume $\left(\mathrm{FEV}_{1}\right)$, chronic respiratory failure, high morbidity and increased health care utilization (2-4). Meanwhile, bronchiectasis is a highly heterogeneous disease and has a range of severity $(5,6)$. On the other hand there were also studies that did not reported any significant association between disease severity index with anxiety and depression. Nevertheless, there is insufficient evidence to determine whether psychological status have an impact on clinical outcomes in patients with non-CF bronchiectasis. Understanding of factors affecting psychological status in patients with bronchiectasis allows to improve treatment plans. We aimed to detect depression and anxiety in patients with non-CF bronchiectasis and to evaluate its relationship with clinical indices, particularly disease severity indexes such as BSI (bronchiectasis severity index) and FACED. 


\section{MATERIALS and METHODS}

\section{Study Populations}

A total number of 90 adult patients with diagnosis of non-CF bronchiectasis consecutively attending the Adult Pulmonology Clinics of Marmara University Hospital were enrolled into the study. The research project was approved by Marmara University Medical Faculty Clinical Research Ethics Committee and patients who met the criteria defined in this study protocol were enrolled into the study after obtaining written informed consents.

The diagnosis of bronchiectasis was made on the basis of clinical history of mucopurulent sputum and radiological confirmation of high resolution computed tomography scanning (HRCT). A radiologist blind to the study interpreted the HRCT scans and assessed the severity of radiologic presentation with evaluation of each lobe. None of the patients had not had any exacerbation for at least four weeks. Exacerbation was defined as a person with bronchiectasis with a deterioration in three or more of the following key symptoms for at least $48 \mathrm{~h}$ : cough; sputum volume and/or consistency; sputum purulence; breathlessness and/or exercise tolerance; fatigue and/or malaise; hemoptysis and a clinician determines that a change in bronchiectasis treatment is required (7). Sweat test for exclusion of cystic fibrosis was performed for all participants. Alpha 1-Antitrypsin deficiency was also evaluated. Patients with cystic fibrosis, malignancy, pregnancy and already known (CVID) were excluded from the study. Medical records were reviewed and a follow-up form for each patient questioning patients' medical history, symptoms, smoking history, education and work status, marital status, concomitant medications and comorbidities using Charlson comorbidity index, past histo$r y$, the duration of disease, the number of disease exacerbations and hospitalizations within the last year, and medical treatment were filled out (8). All patients underwent pulmonary function tests and carbon monoxide diffusion tests according to ATS criteria $(9,10)$, their height and body weight were measured, and Modified Medical Research Council (mMRC) dyspnea score was recorded. The results of investigated respiratory bacteria including pseudomonoas aeroginosa in the sputum were obtained. Radiographic extension was assessed based on the number of bronchiectatic lobes as local (one lob) or expanded.

\section{Disease Severity Indexes}

The severity of bronchiectasis was calculated using indexes such as Bronchiectasis Severity Index (BSI) based on age, body mass index (BMI), forced expiratory volume 1 second $\left(\mathrm{FEV}_{1}\right) \%$ predicted, the number of hospital admission and exacerbation, $\mathrm{mMRC}$, bacterial colonization, the number of involved lobe and FACED score based on age, pseudomonas aeruginosa colonization, $\mathrm{mMRC}, \mathrm{FEV}_{1} \%$ predicted, and the number of involved lobe. Patients were classified into mild (0-4), and moderate-to-severe $(\geq 5)$ for BSI; into mild $(0-2)$ and $(\geq 3)$ moderate-to-severe for FACED (11).

\section{Assessment of Psychological Status}

Participants were asked to fill in the self-reported hospital anxiety and depression scale (HADS) questionnaire validated for Turkish language. The questionnaire consists of 14 questions, in which the overall severity of anxiety and depression is rated on 4-point scale. Seven questions are related to anxiety and 7 to depression (12). The scores are interpreted as following; 0-7 as normal, $\geq 10$ as anxiety risk and $\geq 7$ as depression risk.

\section{Statistics}

All statistical analyses were performed using SPSS 20.0 program. Descriptive statistics for normally distributed continuous data were shown as means \pm standard deviations. Median (minimum-maximum) values were used to assess non-normally distributed data. Categorical variables were compared by Chisquare test and Fisher's Exact test was used if the number of expected values was lower than 5 in fourcell tables. To compare the mean values of continuous variables between two groups, t-test was used for normally distributed and Mann-Whitney $U$ test was used for non-normally distributed data. Correlations between normally distributed data were tested by Pearson correlation analysis and Spearman correlation test was used for non-normally distributed data. A multi-variant logistic regression analysis was performed to test the parameters that had significant correlations with the psychological state. For all analyses, $p$ values $<0.05$ were considered statistically significant.

\section{RESULTS}

In this cross-sectional study, a total of 90 patients (F/M: 48/32) aged 18 years and above, who were 
referred to the Pulmonary Medicine outpatient clinic and were diagnosed with non-CF stable bronchiectasis, were included in the final analysis. Among the 118 patients with bronchiectasis who had been referred to the outpatient clinic, 3 patients with a previously diagnosed common variable immunodeficiency disease and 10 patients with cystic fibrosis were excluded from the study. Five patients did not provide consent for participation and thus were also excluded from the study.

Overall, 24 (27\%) patients had normal, 36 (40\%) patients had mixed, 20 (22\%) had obstructive, and $10(11 \%)$ had restrictive lung function tests. Twentytwo (24\%) patients had Pseudomonas aeruginosa growth in sputum culture. Demographic data; clinical, functional, and radiological status, microbiology, and disease severity of the entire study population are depicted in Table 1. Among the study population, 90 patients were classified as having mild 46 (51\%) and $44(49 \%)$ as having moderate-to-severe according to BSI severity index, 60 (67\%) patients as having mild and $30(33 \%)$ patients as having moderate-to-severe based on FACED severity index. Differences among these groups in terms of demographics, clinical, functional, and radiological status, and microbiology are depicted in Table 1. As illustrated in Table $2 \mathrm{BSI}$ and FACED severity indexes increased with longer duration of disease $(5.6 \pm 5.0 \mathrm{yrs}$ in mild group vs. $10.1 \pm 9.2 \mathrm{yrs}$ in moderate-severe group, $\mathrm{p}=0.035$ and $5.7 \pm 5.4 \mathrm{yrs}$ in mild group vs. $12.1 \pm$ 9.7 yrs in moderate-severe group, $p=0.001$, respectively).

Anxiety was diagnosed in $27(30 \%)$ of patients and depression was diagnosed in 37 (41\%) of 90 non-CF patients with bronchiectasis. Female patients had increased risk for depression $(55 \%$ vs. $22 \%$, $p=$ 0.002). Anxiety was related with high exacerbation rate within the last year $(p=0.007)$ and depression

Table 1. Baseline characteristics of the patients with bronchiectasis $(n=90)$

\begin{tabular}{|c|c|c|c|c|c|c|}
\hline & $\begin{array}{c}\text { Depression } \\
(n=37)\end{array}$ & $\begin{array}{l}\text { No-depression } \\
\quad(n=53)\end{array}$ & $\mathbf{p}$ & Anxiety $(n=27)$ & $\begin{array}{c}\text { No-anxiety } \\
(n=63)\end{array}$ & $\mathbf{p}$ \\
\hline Age, years & $45.9 \pm 14.7$ & $44.6 \pm 18.2$ & 0.640 & $41.2 \pm 14.3$ & $46.9 \pm 17.6$ & 0.181 \\
\hline Female gender, \% & 78.4 & 45.3 & 0.002 & 74.1 & 52.4 & 0.055 \\
\hline $\mathrm{BMI}, \mathrm{kg} / \mathrm{m}^{2}$ & $26.9 \pm 5.8$ & $24.8 \pm 5.5$ & 0.095 & $24.9 \pm 6.2$ & $26.0 \pm 5.6$ & 0.400 \\
\hline Current smoker, \% & 83.8 & 83.0 & 0.924 & 81.5 & 84.1 & 0.758 \\
\hline Tuberculosis, \% & 18.9 & 13.2 & 0.462 & 11.1 & 17.5 & 0.446 \\
\hline Pseudomonas, \% & 75.7 & 75.5 & 0.982 & 70.4 & 77.8 & 0.454 \\
\hline Oxygen usage, \% & 8.1 & 7.5 & 0.922 & 3.7 & 9.5 & 0.345 \\
\hline NIMV usage, $\%$ & 2.7 & 5.7 & 0.503 & 3.7 & 4.8 & 0.823 \\
\hline Bronchodilator usage, $\%$ & 67.6 & 76.5 & 0.355 & 70.4 & 73.8 & 0.741 \\
\hline Steroid usage, \% & 8.1 & 5.7 & 0.647 & 11.1 & 4.8 & 0.268 \\
\hline Localized disease, $\%$ & 16.2 & 11.3 & 0.501 & 7.4 & 15.9 & 0.279 \\
\hline Duration, years & $5.4 \pm 6.0$ & $9.5 \pm 8.3$ & 0.004 & $6.8 \pm 6.8$ & $8.3 \pm 8.0$ & 0.452 \\
\hline Exacerbation, $\mathrm{n}$ & $3.0 \pm 2.0$ & $2.7 \pm 1.9$ & 0.497 & $3.7 \pm 2.0$ & $2.5 \pm 1.8$ & 0.007 \\
\hline $\mathrm{FEV}_{1} \%$ & $65.2 \pm 31.0$ & $66.7 \pm 28.2$ & 0.566 & $66.6 \pm 35.8$ & $65.8 \pm 26.2$ & 0.625 \\
\hline FVC \% & $76.8 \pm 28.7$ & $79.6 \pm 23.4$ & 0.303 & $78.8 \pm 32.1$ & $78.3 \pm 22.6$ & 0.576 \\
\hline $\mathrm{FEV}_{1} / \mathrm{FVC} \%$ & $70.4 \pm 13.1$ & $67.7 \pm 14.7$ & 0.486 & $69.5 \pm 12.9$ & $68.4 \pm 14.6$ & 0.741 \\
\hline MMEF \% & $40.7 \pm 32.6$ & $45.3 \pm 36.6$ & 0.974 & $42.0 \pm 37.3$ & $44.0 \pm 34.2$ & 0.725 \\
\hline MMRC score & $1.7 \pm 1.0$ & $1.5 \pm 0.9$ & 0.277 & $1.6 \pm 1.1$ & $1.6 \pm 0.9$ & 0.978 \\
\hline Charlson score & $1.6 \pm 1.0$ & $1.3 \pm 0.6$ & 0.152 & $1.6 \pm 1.1$ & $1.4 \pm 0.7$ & 0.733 \\
\hline Moderate-to-severe MMRC, \% & 51.4 & 41.5 & 0.356 & 44.4 & 46.0 & 0.890 \\
\hline Moderate-to-severe BSI, \% & 48.6 & 49.1 & 0.970 & 51.9 & 47.6 & 0.713 \\
\hline Moderate-to-severe FACED, \% & 29.7 & 35.8 & 0.545 & 33.3 & 33.3 & 1.000 \\
\hline
\end{tabular}


Bekir M, Kocakaya D, Balcan B, Olgun Yıldızeli Ş, Eryüksel E, Ceyhan B.

Table 2. Comparison of mild BSI with moderate-to-severe BSI as well as mild FACED with moderate-to-severe FACED in patients with bronchiectasis $(\mathrm{n}=90)$

\begin{tabular}{|c|c|c|c|c|c|c|}
\hline & $\begin{array}{l}\text { Mild BSI } \\
(n=46)\end{array}$ & $\begin{array}{l}\text { Moderate-to-severe } \\
\quad \text { BSI }(n=44)\end{array}$ & $\mathbf{p}$ & $\begin{array}{l}\text { Mild FACED } \\
\quad(n=60)\end{array}$ & $\begin{array}{l}\text { Moderate-to-severe } \\
\text { FACED }(n=30)\end{array}$ & p \\
\hline Age, years & $43.7 \pm 13.6$ & $46.6 \pm 19.6$ & 0.487 & $44.9 \pm 14.0$ & $45.5 \pm 21.6$ & 0.997 \\
\hline Female gender, $\%$ & 43.4 & 46.1 & 0.875 & 47.4 & 49.2 & 0.896 \\
\hline BMI, $\mathrm{kg} / \mathrm{m}^{2}$ & $27.1 \pm 5.7$ & $24.2 \pm 5.4$ & 0.020 & $26.9 \pm 5.6$ & $23.1 \pm 5.2$ & 0.903 \\
\hline Current smoker, \% & 82.6 & 84.1 & 0.850 & 85.0 & 80.0 & 0.549 \\
\hline Tuberculosis, \% & 17.4 & 13.6 & 0.623 & 15.0 & 16.7 & 0.837 \\
\hline Pseudomonas, \% & 95.7 & 54.5 & $<0.001$ & 85.0 & 56.7 & 0.003 \\
\hline Oxygen usage, \% & 4.3 & 11.4 & 0.214 & 3.3 & 16.7 & 0.026 \\
\hline NIMV usage, \% & 2.2 & 6.8 & 0.285 & 1.7 & 10.0 & 0.071 \\
\hline Bronchodilator usage, $\%$ & 60.0 & 86.0 & 0.006 & 64.4 & 89.7 & 0.012 \\
\hline Steroid usage, $\%$ & 8.7 & 4.5 & 0.430 & 6.7 & 6.7 & 1.000 \\
\hline Localized disease, \% & 19.6 & 6.8 & 0.075 & 16.7 & 6.7 & 0.188 \\
\hline Duration, years & $5.6 \pm 5.0$ & $10.1 \pm 9.3$ & 0.035 & $5.7 \pm 5.4$ & $12.1 \pm 9.6$ & 0.001 \\
\hline Exacerbation, $\mathbf{n}$ & $2.2 \pm 1.6$ & $3.6 \pm 2.1$ & $<0.001$ & $2.6 \pm 1.7$ & $3.5 \pm 2.7$ & 0.071 \\
\hline $\mathrm{FEV}_{1} \%$ & $75.4 \pm 25.8$ & $56.4 \pm 29.7$ & $<0.001$ & $75.8 \pm 27.9$ & $46.7 \pm 21.3$ & $<0.001$ \\
\hline FVC $\%$ & $85.7 \pm 24.1$ & $70.9 \pm 25.3$ & 0.001 & $87.0 \pm 25.0$ & $61.4 \pm 16.9$ & $<0.001$ \\
\hline FEV1/FVC \% & $73.5 \pm 12.4$ & $63.8 \pm 14.1$ & 0.001 & $72.4 \pm 12.1$ & $61.5 \pm 15.0$ & 0.001 \\
\hline MMEF \% & $52.8 \pm 32.5$ & $33.6 \pm 34.9$ & $<0.001$ & $51.0 \pm 35.1$ & $28.2 \pm 29.5$ & $<0.001$ \\
\hline MMRC score & $1.1 \pm 0.8$ & $2.0 \pm 0.9$ & $<0.001$ & $1.3 \pm 0.8$ & $2.2 \pm 1.0$ & $<0.001$ \\
\hline Charlson score & $1.3 \pm 0.6$ & $1.6 \pm 1.0$ & 0.332 & $1.3 \pm 0.6$ & $1.7 \pm 1.2$ & 0.129 \\
\hline Anxiety positive, $\%$ & 28.3 & 31.8 & 0.713 & 30 & 30 & 1.000 \\
\hline Depression positive, $\%$ & 41.3 & 40.9 & 0.970 & 43.3 & 36.7 & 0.545 \\
\hline Moderate-to-severe MMRC, \% & 28.3 & 63.6 & 0.001 & 35.0 & 66.7 & 0.004 \\
\hline
\end{tabular}

with shorter duration of the disease $(p=0.004)$ (Table 3, Figure 1). As shown in Table 2 work status is related with depression but not with anxiety, housewives had an increased risk for depression with the $65 \%$ of all depressives were housewives $(p=0.006)$. The depression scores negatively correlated with the duration of disease $(p=0.003)$ and anxiety scores correlated with the exacerbation rate within last year $(p=0.008)$ (Figure 1$)$. In the study population, BSI and FACED severity indexes increased with longer duration of disease $(p=0.035$ and $p=0.001$, respectively), however, anxiety and depression were not related with BSI and FACED severity indexes (Table 3). For identifying risk factors for depression and anxiety, we included the age, BMI, gender, frequency of exacerbations and hospitalizations, mMRC score, $\mathrm{FEV}_{1} \%$ pred, severity indexes as independent vari- ables in multivariate logistic regression. As illustrated in Table 3, when the patients are grouped based on gender, female patients had statistically higher rates of depression than male patients $(\mathrm{OR}=0.196, \mathrm{Cl}=$ 0.073-0.528).

Patients with pseudomonas colonization was $24 \%$ in our study population; we observed worse lung function and radiological severity when compared to uninfected patients. Moreover, Pseudomonas colonization is associated with consistent and significant increases in all markers of disease severity including exacerbation and hospitalization within last year. However, there were no differences in pathogenic microorganisms such as pseudomonas and other colonized microorganisms between patients with psychological problems or not. 
Table 3. Variables associated with depression and anxiety in patients with bronchiectasis

\begin{tabular}{|c|c|c|c|c|c|c|}
\hline & \multicolumn{3}{|c|}{ Depression } & \multicolumn{3}{|c|}{ Anxiety } \\
\hline & OR & $95 \% \mathrm{Cl}$ & $\mathbf{p}$ & OR & $95 \% \mathrm{Cl}$ & $\mathbf{p}$ \\
\hline \multicolumn{7}{|l|}{ Univariate } \\
\hline Age & 0.99 & 0.97-1.02 & 0.723 & 1.02 & 0.99-1.05 & 0.141 \\
\hline Female gender & 4.38 & $1.69-11.34$ & 0.002 & 2.59 & $0.96-7.01$ & 0.059 \\
\hline Current smoker & 1.06 & $0.34-3.27$ & 0.924 & 0.83 & $0.25-2.71$ & 0.830 \\
\hline $\mathrm{BMI}$ & 0.94 & $0.87-1.01$ & 0.095 & 1.04 & $0.96-1.12$ & 0.396 \\
\hline Tuberculosis & 1.53 & $0.49-4.81$ & 0.464 & 0.59 & $0.15-2.31$ & 0.450 \\
\hline Duration & 1.09 & $1.02-1.18$ & 0.017 & 1.03 & 0.96-1.09 & 0.411 \\
\hline Exacerbation & 0.93 & $0.75-1.15$ & 0.490 & 0.73 & $0.57-0.93$ & 0.011 \\
\hline Pseudomonas & 1.01 & $0.38-2.69$ & 0.982 & 0.68 & $0.25-1.88$ & 0.455 \\
\hline Charlson score & 0.66 & $0.39-1.11$ & 0.118 & 0.66 & $0.39-1.11$ & 0.118 \\
\hline Oxygen usage & 1.08 & $0.23-5.14$ & 0.922 & 1.08 & $0.23-5.14$ & 0.922 \\
\hline NIMV usage & 0.46 & $0.05-4.63$ & 0.512 & 0.77 & $0.08-7.75$ & 0.824 \\
\hline Bronchodilator usage & 0.64 & $0.25-1.65$ & 0.356 & 0.84 & $0.31-2.30$ & 0.741 \\
\hline Steroid usage & 1.47 & $0.28-7.72$ & 0.649 & 2.50 & $0.47-13.27$ & 0.282 \\
\hline Localized disease & 1.52 & $0.45-5.13$ & 0.503 & 0.42 & $0.09-2.08$ & 0.290 \\
\hline MMRC score & 0.79 & $0.52-1.21$ & 0.279 & 0.96 & $0.61-1.52$ & 0.817 \\
\hline Mod-to-severe MMRC & 0.67 & $0.29-1.56$ & 0.357 & 1.07 & $0.43-2.64$ & 0.890 \\
\hline Mod-to-severe BSI & 1.02 & $0.44-2.36$ & 0.970 & 0.84 & $0.34-2.08$ & 0.713 \\
\hline Mod-to-severe FACED & 1.32 & $0.54-3.25$ & 0.545 & 1.00 & $0.38-2.60$ & 1.000 \\
\hline $\mathrm{FEV}_{1} \%$ & 1.00 & $0.99-1.02$ & 0.816 & 0.99 & $0.98-1.02$ & 0.908 \\
\hline FVC $\%$ & 1.00 & $0.99-1.02$ & 0.609 & 0.99 & $0.98-1.02$ & 0.921 \\
\hline FEV1/FVC \% & 0.99 & $0.96-1.02$ & 0.384 & 0.99 & $0.96-1.03$ & 0.733 \\
\hline MMEF \% & 1.00 & $0.99-1.02$ & 0.532 & 1.00 & $0.99-1.02$ & 0.809 \\
\hline \multicolumn{7}{|l|}{ Multivariate } \\
\hline Age & 1.01 & $0.98-1.04$ & 0.497 & 1.02 & $0.99-1.05$ & 0.238 \\
\hline Female gender & 5.15 & $1.88-14.01$ & 0.001 & 2.83 & $0.98-8.12$ & 0.054 \\
\hline Duration & 1.11 & $1.03-1.21$ & 0.009 & 0.74 & $0.57-0.96$ & 0.024 \\
\hline
\end{tabular}

\section{DISCUSSION}

In the current study we observed that anxiety and depression are common comorbidities with particularly an increased depression risk for female patients, particularly for housewives. Anxiety was related with high exacerbation rate within the last year and depression was inversely associated with shorter duration of the disease. Interestingly, no clinically important differences in psychological status were present across different levels of disease severity, exception of increased bronchectasis disease severity indexes with longer duration of disease.
To date, there have been few studies investigating mental health state of non-CF patients with bronchectasis. The anxiety and depression are common comorbidities among patients with bronchiectasis, and the rate of depression risk was $41 \%$ in the present study with particularly high risk for females. Our results are in agreement with previous bronchiectasis studies assessing risk factors for depression and anxiety. In a Korean study that assessed depression and anxiety in patients with COPD, asthma, and bronchiectasis, they found depression in $55 \%$ of patients with COPD and $55 \%$ of patients with bronchiectasis however only patients with bronchiectasis demon- 


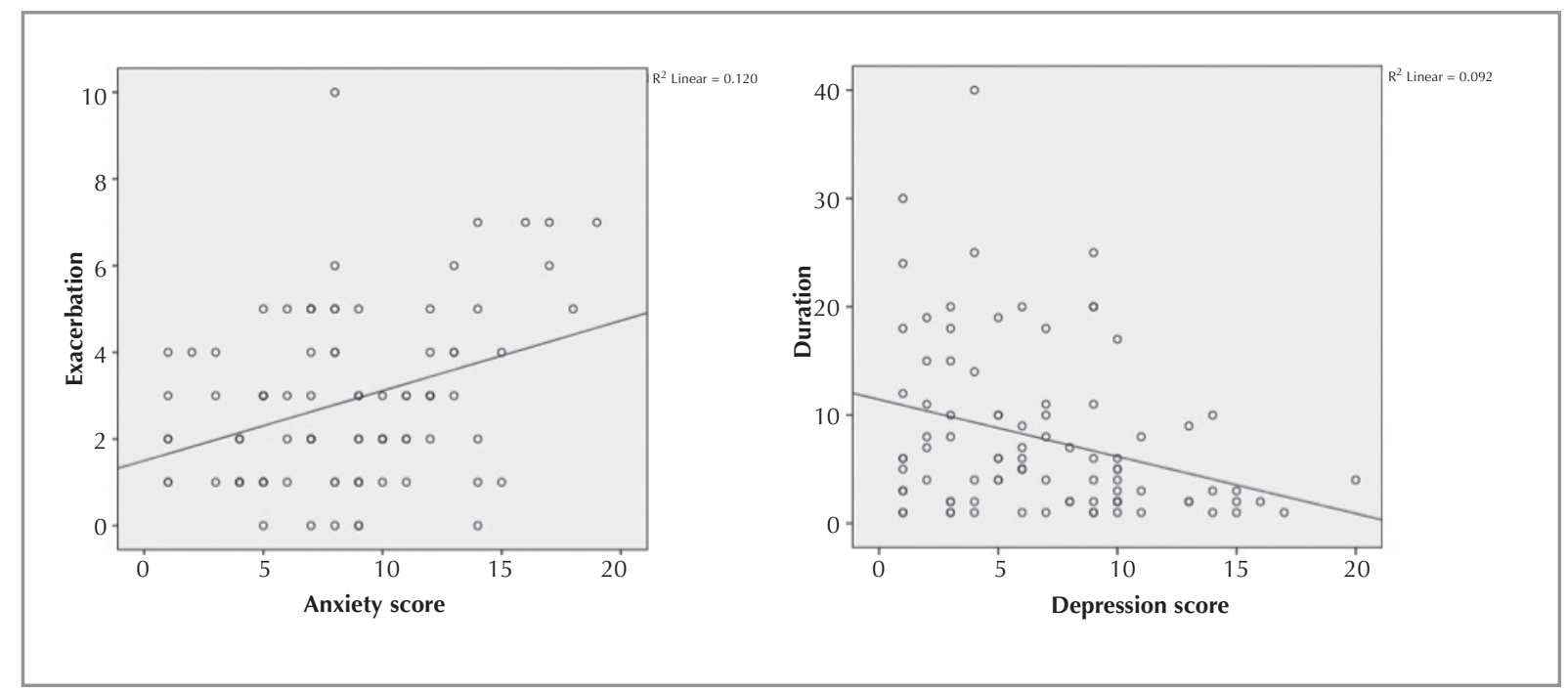

Figure 1. Correlation between anxiety score and exacerbation as well as depression score and disease duration.

strated anxiety not COPD patients. Decreased lung function and a history of smoking were independent risk factors for depression for all groups (2). Moreno et al found that $34 \%$ of patients with bronchiectasis had depression and $55 \%$ of patients with bronchiectasis had anxiety and depression was higher in female patients when compared with male patients using STAI and BDI questionnaires (13). The Spanish historical registry of bronchiectasis studied 2099 non-CF bronchiectasis patients and reported the diagnostic delay for women 2.1 years more than for men (14). The females' delayed diagnosed symptoms might be a factor for worse disease control and depression or vice versa. The sex was the sole factor associated with depression in multivariate regression analysis in our study. In general population, two or three times higher prevalence of depression in female patients is a fact (15). Moreover, we found that work status was related with depression but not with anxiety and housewiwes had increased risk for depression. Our data seem to be in line with recent study by Olveira et al demonstrating that women who were unemployed had higher depression scores than women who were employed (16). These findings call for appropriate approach to improve the mental health of non-CF patients with, particularly females. Interestingly, depression was related with shorter duration of disease which led us to speculate that this group might have immature coping skills to accept the disease and to adhere to treatment with increasing years it may be easy to cope with disease. To the best of our knowledge, this is the first report in term of effect of duration of disease on depression risk. This may allow novel insight into our understanding of possible factors related to depression and to screen early the bronchiectatic patients for depression.

We found the anxiety risk in $30 \%$ of patients, this result is consistent with prior studies in which higher rates of anxiety have been reported such as $38 \%$ and $39.8 \%(3,16)$. The finding of a high prevalance of anxiety was found to be related with high exacerbation rate within the last year in the patients with nonCF bronchiectasis in our study. Similarly, anxiety was related with frequent exacerbations in these previous studies $(3,16)$. In a Chinese study, anxiety was related by sleep disturbances, daytime cough, younger age and lower education level in patients with bronchiectasis (17). Our study found that pseudomonas colonisation was present in $24 \%$ of patients which is similar to previous reports. Living with a partner and bacterial colonization especially pseudomonas was related to anxiety in previous studies $(3,16)$. Wang $\mathrm{H}$ et al. reported worse scores for anxiety and depression on HADS scale in patients with Pseudomonas colonization (18). However, we did not find these risk factors for anxiety in our study. This discordance might reflect the differences in patient characteristics, comorbidities, different treatment modalities, different microbial distribution between different countries which could result in these disparities. On the other hand, the present study only assessed the associations, we could not infer the causality. The worse disease control and consequently several exacerba- 
tions might cause to frequent anxiety symptoms. Anxiety may lead a patient to report worse aspects of symptoms, and vice versa.

In the study population, no significant differences in the rate of anxiety and depression were found according to the severity of disease. Notably, FACED and BSI scores are more skewed towards mild bronchiectasis and both severity scores showed a large disparity, suggesting the distinction of both scoring

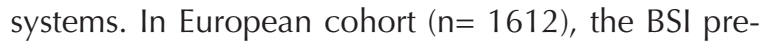
dicted hospitalizations, exacerbations, quality of life, respiratory symptoms, across all risk categories. FACED had poor discrimination for hospital admissions and did not predict future risk of exacerbations and quality of life (19). Similar to our results, neither anxiety nor depression correlated with bronchiectasis severity assessed with both BSI and FACED score in a Chinese study (17). Similarly, in a study assessing 117 patients with bronchiectasis, neither anxiety nor depression was associated with the extent of bronchiectasis on CT scan that is a determinant of severity scores (20). Moreover, in the present study, both BSI and FACED severity indexes increased with longer duration of disease, a significant higher prevalance of patients with moderate-to-severe disease with longer duration of disease in comparison to those with mild disease. It might be suggested that patients with bronchiectasis will appear to have more severe disease with long lasting disease. This association has not been reported previously.

This study also has some limitations that should be taken into consideration. Our study was conducted at a single center. This study design is cross-sectional and the estimation of the long term impact of psychological status on functional decline and disease progression and adverse outcomes including exacerbations, hospitalization were not evaluated prospectively. The different questionnaires except HADS such as STAI and BDI questionnaires might result in discordance in the rates of psychological status when comparing with other studies. The other limitation is that all patients are not consulted by a professional psychiatrist and only assessed by questionnaires.

There are scant data regarding clinical implications of psychological status in patients with non-CF bronchiectasis patients. This study demonstrates that the prevalence of depression is higher in female patients than male patients with non-CF bronchiectasis. Anxiety was related with high exacerbation rate with- in the last year and depression with longer duration of the disease. Additionally, our results indicate that the disease severity might not be an adequate marker for physicians to suspect psychological problems. According to these findings, we suggest that all symptomatic patients with bronchiectasis, regardless of severity, should undergo detailed testing to detect psychological problems. Although many advances have been made in the treatment against respiratory systems in bronchiectatic patients, they can not receive the care for potential complex mental health problems and social care needs. There is also a lack of collaboration in the design and coordination of different health services. Early treatment of depression and anxiety in this population could prevent worsening of life quality, even in patients with low-severity disease. Our study will be followed by further studies to clearly define the specific nature of mental health and clinically important outcomes in patients with non-CF bronchiectasis.

\section{ACKNOWLEDGEMENT}

We would like to thank to Dr. Seyma Gorgin for help for statistic analysis.

\section{CONFLICT of INTEREST}

The authors declare that there are no conflicts of interest.

\section{AUTHORSHIP CONTRIBUTIONS}

Concept/Design: MB, BC

Analysis/Interpretation: BB

Data Acquisition: ŞOY, DK, EE

Writting: $\mathrm{BC}, \mathrm{BB}$

Critical Revision: $\mathrm{BB}$

Final Approval: BC

\section{REFERENCES}

1. KKaton W, Lin EH, Kroenke K. The association of depression and anxiety with medical symptom burden in patients with chronic medical illness. Gen Hosp Psychiatry 2007;29(2):147-55.

2. Ryu YJ, Chun EM, Lee JH, Chang JH. Prevalence of depression and anxiety in outpatients with chronic airway lung disease. Korean J Intern Med 2010;25(1):51-7.

3. Ozgun Niksarlioglu EY, Ozkan G, Gunluoglu G, Uysal MA, Gul S, Kilic L, et al. Factors related to depression and anxiety in adults with bronchiectasis. Neuropsychiatr Dis Treat 2016;12:3005-10. 
4. Boussoffara L, Boudawara N, Gharsallaoui Z, Sakka M, Knani J. Anxiety-depressive disorders and bronchiectasis. Rev Mal Respir 2014;31(3):230-6.

5. Chalmers JD, Goeminne P, Aliberti S, McDonnell MJ, Lonni $S$, Davidson J, et al. The bronchiectasis severity index. An international derivation and validation study. Am / Respir Crit Care Med 2014;189(5):576-85.

6. Martinez-Garcia MA, de Gracia J, Vendrell Relat M, Giron RM, Maiz Carro L, de la Rosa Carrillo D, et al. Multidimensional approach to non-cystic fibrosis bronchiectasis: the FACED score. Eur Respir / 2014;43(5):135767.

7. Hill AT, Haworth CS, Aliberti S, Barker A, Blasi F, Boersma $W$, et al. Pulmonary exacerbation in adults with bronchiectasis: a consensus definition for clinical research. Eur Respir J 2017;49(6).

8. Charlson ME, Pompei P, Ales KL, MacKenzie CR. A new method of classifying prognostic comorbidity in longitudinal studies: development and validation. J Chronic Dis 1987;40(5):373-83.

9. Macintyre $N$, Crapo RO, Viegi $G$, Johnson $D C$, van der Grinten CP, Brusasco V, et al. Standardisation of the singlebreath determination of carbon monoxide uptake in the lung. Eur Respir J 2005;26(4):720-35.

10. Miller MR, Hankinson J, Brusasco V, Burgos F, Casaburi R, Coates $A$, et al. Standardisation of spirometry. Eur Respir J 2005;26(2):319-38.

11. Minov J, Karadzinska-Bislimovska J, Vasilevska K, Stoleski $S$, Mijakoski D. Assessment of the non-cystic fibrosis bronchiectasis severity: the FACED score vs. the bronchiectasis severity index. Open Respir Med I 2015;9:46-51.

12. Zigmond AS, Snaith RP. The hospital anxiety and depression scale. Acta Psychiatr Scand 1983;67(6):361-70.
13. Giron Moreno RM, Fernandes Vasconcelos G, Cisneros C, Gomez-Punter RM, Segrelles Calvo G, Ancochea J. Presence of anxiety and depression in patients with bronchiectasis unrelated to cystic fibrosis. Arch Bronconeumol 2013;49(10):415-20.

14. Giron RM, de Gracia Roldan J, Olveira C, Vendrell M, Martinez-Garcia MA, de la Rosa D, et al. Sex bias in diagnostic delay in bronchiectasis: An analysis of the Spanish Historical Registry of Bronchiectasis. Chron Respir Dis 2017; 14(4):360-9

15. Zhang YS, Rao WW, Cui LJ, Li JF, Li L, Ng CH, et al. Prevalence of major depressive disorder and its sociodemographic correlates in the general adult population in Hebei province, China. J Affect Disord 2019;252:92-8.

16. Olveira C, Olveira G, Gaspar I, Dorado A, Cruz I, Soriguer $F$, et al. Depression and anxiety symptoms in bronchiectasis: associations with health-related quality of life. Qual Life Res 2013;22(3):597-605.

17. Gao YH, Guan WJ, Zhu YN, Chen RC, Zhang GJ. Anxiety and depression in adult outpatients with bronchiectasis: Associations with disease severity and health-related quality of life. Clin Respir J 2018;12(4):1485-94.

18. Wang H, Ji XB, Mao B, Li CW, Lu HW, Xu JF. Pseudomonas aeruginosa isolation in patients with non-cystic fibrosis bronchiectasis: a retrospective study. BMJ Open 2018;8(3):e014613.

19. McDonnell MJ, Aliberti S, Goeminne PC, Dimakou K, Zucchetti SC, Davidson J, et al. Multidimensional severity assessment in bronchiectasis: an analysis of seven European cohorts. Thorax 2016;71(12):1110-8.

20. O'Leary CJ, Wilson CB, Hansell DM, Cole PJ, Wilson R, Jones PW. Relationship between psychological well-being and lung health status in patients with bronchiectasis. Respir Med 2002;96(9):686-92. 